\title{
Trials of vaccine against AIDS to begin in humans
}

\section{- Safety and immunogenicity tests in October - Other vaccines on the way}

\section{Washington}

MicroGeneSys has won the race to be the first in the United States to win approval to test a vaccine for AIDS (acquired immune deficiency syndrome) in humans. Last week the Food and Drug Administration gave MicroGeneSys permission to begin clinical trials in October.

The Phase I study will test only the safety and immunogenicity of the proposed vaccine. Eighty-one volunteers - seventy-five homosexual men and six people with no history of risk behaviour - will participate in the trial at the US National Institutes of Health (NIH). Eighteen of the volunteers will be given a substitute injection, to serve as a control group.

Male homosexuals were chosen as subjects for testing the vaccine because AIDS has hit hardest in this section of the population. Homosexuals have often also been exposed to other viral infections at higher rates than in the general population, and so may have different immunological profiles. If the proposed vaccine proves to be safe in the six-month Phase I study, further volunteers will be added in the following year in Phase II, to determine the appropriate dose. But effectiveness will not be evaluated until Phase III.

Because it will not be ethically possible to challenge vaccinated humans with the AIDS virus directly, a long-term prospective study will probably be needed to determine the vaccine's ability to prevent infection.

MicroGeneSys collaborated with researchers at NIH in developing the vaccine, which consists of the gp 160 protein from the envelope of the HIV (human immunodeficiency virus), the virus that causes AIDS. Most current AIDS research is concentrated on the envelope proteins because these are thought to be capable of producing the strongest immunological response. MicroGeneSys produces gp160 by recombinant means, using an insect cell-line expression system and a baculovirus vector. Because the vaccine is not derived from whole or live virus, there is no chance that it can cause AIDS.

Anthony Fauci, director of the National Institute for Allergy and Infectious Diseases at $\mathrm{NIH}$, says the gp160 protein evokes high levels of neutralizing antibodies and a good cell-mediated response when administered to small mammals, rhesus monkeys and chimpanzees. But chimpanzees - the only animals other than man capable of being infected with the AIDS virus - were not challenged by the AIDS virus to determine if the vaccine was effective in preventing infection.

Jorg Eichberg, a leading researcher in evaluating animal models for testing AIDS vaccines, says it is "preposterous to put it in people" before evaluating it fully in chimpanzees. But Fauci replies that infected chimpanzees do not go on to develop AIDS, so that data about the efficacy of the vaccine in chimpanzees may not be transferable to humans.

Another candidate vaccine, which has been developed by the Bristol-Myers subsidiary Oncogen, has been shown to be ineffective in preventing infection in chimpanzees (see Nature 328, 721-723; 1987) but is nevertheless expected to be used in trials in humans by the end of the year, according to Oncogen's Shiu-Lok $\mathrm{Hu}$. This vaccine is based on a recombinant vaccinia virus that expresses the genes for the HIV envelope proteins.

Most of the other companies working on an AIDS vaccine are studying gp120, the external portion of the HIV envelope protein. Laurence Lasky of Genentech says the company has tested gp120 expressed in mammalian cells in chimpanzees, but will not discuss the results. Chiron is collaborating with Ciba-Geigy to produce gp120 in yeast, and Repligen has teamed up with Merck \& Company to work on gp120 and gp160. Cambridge Bioscience is trying out a variety of approaches, joining Institut Merieux of France to study several viral subunit proteins, a vaccinia virus-based vaccine, and anti-idiotypic antibodies.

Paul Luciw of the University of California at Davis says the bulk of the AIDS vaccine work has been on this protein because it has shown promise in animal studies, and the gp160 protein is difficult to produce. He says there are potential problems with a gp160 or gp120 vaccine. The protein could promote the fusion of $\mathrm{T}$ cells in the immune system by binding to the CD4 receptor on those cells. Alternatively, gp160 or gp120 could bind to $T$ cells and cause them to be earmarked for destruction by the immune system, wiping out the very population of cells the vaccine was designed to protect.

Fauci calls these "way-out possibilities", and says there is no indication of immunological aberration in animal tests done so far. Besides, he says, "the only way to tell would be a limited Phase I study in humans".

\section{Surprise money for UK space}

\section{London}

Having flatly declared last month that no more money was available for British space research, the government last week produced an extra $£ 4$ million, sufficient to keep open Britain's options in the European Space Agency (ESA) research programme.

Roy Gibson, director general of the British National Space Centre (BNSC), the body which coordinates civil space research in Britain, announced his resignation on 4 August when he was told that not only was BNSC's strategic plan, which requested an increase in spending from around $£ 100$ million annually to nearer $£ 300$ million, being rejected, but that a further $£ 7$ million would not be forthcoming to tide over various domestic and collaborative projects until ESA's ministerial meeting in November.

Last week the Department of Trade and

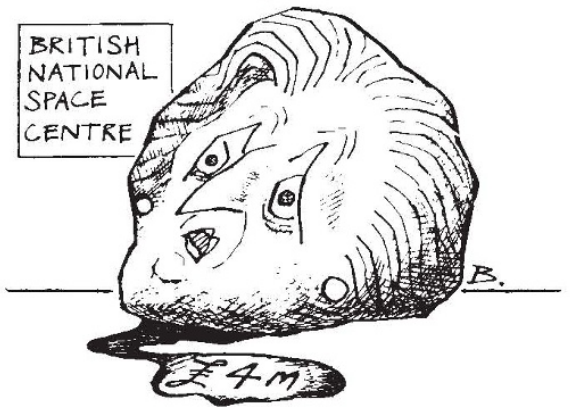

\section{BLOOD OUT OF A STONE}

Industry (DTI), BNSC's parent body, announced that an arrangement had been reached with aerospace companies involved in the domestic space programme, notably British Aerospace and RollsRoyce, whereby the companies would take over the government's portion of the spending, amounting to around $£ 3$ million. The main projects affected are studies on the Hotol space plane and Radarsat, a collaborative venture between Britain and Canada.

The government says that in view of the 'positive' response from industry, an extra £4 million will be provided from DTI's research budget to keep Britain in the running for contracts on Ariane $V$ and Columbus if the projects are given the goahead at ESA's November meeting. Britain's space community sees the extra cash as a small but promising indication that the government is willing to keep its options open until its own review of civil research and development scheduled for October, and the ESA meeting.

The change of mind followed pressure from industrialists and ESA representatives during recent meetings with the government. Simon Hadlington 